Marquette University

e-Publications@Marquette

Economics Faculty Research and Publications

Economics, Department of

$1-1-2004$

\title{
A Global Lottery and a Global Premium Bond
}

Tony Addison

United Nations University

Abdur Chowdhury

Marquette University, abdur.chowdhury@marquette.edu

Published version. "A Global Lottery and a Global Premium Bond," in New Sources of Development Finance. Ed. A.B. Atkinson. Oxford: Oxford University Press, 2005: 156-177. DOI. (C) 2005 Oxford University Press. Used with permission. 


\title{
A Global Lottery and a Global Premium Bond
}

\author{
TONY ADDISON AND ABDUR R. CHOWDHURY
}

\subsection{INTRODUCTION}

The use of lotteries by national and local/regional governments to raise funds for public sector and charity projects is now commonplace across the world. In 2001, there were at least 177 public (national and local government) lotteries in operation, with combined sales amounting to over US\$120 billion (see Table 8.1). Given the scale of the revenues raised, it is natural to ask whether lotteries could also be used to provide funds for global development programmes. Proposals to establish a global lottery to fund UN development activities have circulated since at least the early 1970s. In 1994, Erskine Childers and Brian Urquhart proposed that: 'One possibility for income moving more directly to the $\mathrm{UN}$ - but still with government licensing in each country — would be an annual United Nations Lottery, administered by a special authority under the Secretary-General' (Childers and Urquhart 1994: 155). The idea of a global lottery has recently been given a major impetus by a former President of Finland, Mr Martti Ahtisaari, together with the Finnish NGO (non-governmental organization), Crisis Management Initiative (CMI), and the Ministry for Foreign Affairs of Finland.

In this chapter, we evaluate proposals for a global lottery. We also propose a complement to the global lottery, namely a global premium bond (which we dub the 'global ERNIE', after the UK's long-running premium bond scheme). The return on both a lottery ticket and a premium bond depends on a random prize draw but, unlike a lottery ticket, a buyer of a premium bond does not lose the initial stake: consequently this instrument has the characteristics of a savings product, making it potentially attractive to ethical investors.

Paper prepared for the UN-DESA and UNU-WIDER project on 'Innovative Sources for Development Finance' directed by Tony Atkinson, Nuffield College, University of Oxford. We thank Tony Atkinson, John Micklewright, David Mayes, and Antti Pentikäinen as well as other participants in the first project meeting and the conference 'Sharing Global Prosperity' (Helsinki, September 2003) for useful comments on earlier drafts. Hirut Arega-Pentikäinen provided excellent research assistance. Helpful points arose in discussions with Tilman Brück, Alberta Hagan, Ian Kinniburgh, Mark McGillivray, and Adam Swallow. Any remaining errors are our own. The views expressed are those of the authors alone, and should not necessarily be attributed to UN-DESA, UNU-WIDER, or UN-ECE. 
Table 8.1. World lottery sales by region, 1996-2001 (US\$ millions)

\begin{tabular}{llllllll}
\hline Africa & $\begin{array}{l}\text { Asia \& } \\
\text { Middle } \\
\text { East }\end{array}$ & $\begin{array}{l}\text { Australia \& } \\
\text { New } \\
\text { Zealand }\end{array}$ & Europe & $\begin{array}{l}\text { North } \\
\text { America }\end{array}$ & $\begin{array}{l}\text { Central \& } \\
\text { South } \\
\text { America }\end{array}$ & Total \\
\hline 1996 & 289.0 & $14,900.0$ & $2,888.7$ & $56,274.4$ & $42,394.3$ & $3,951.9$ & $120,698.3$ \\
1997 & 280.0 & $14,300.0$ & $2,600.0$ & $55,000.0$ & $42,600.0$ & $4,200.0$ & $118,980.0$ \\
1998 & 272.8 & $13,391.0$ & $2,334.8$ & $61,246.6$ & $42,825.6$ & $4,114.9$ & $124,185.7$ \\
1999 & 190.8 & $14,561.6$ & $2,469.5$ & $63,481.1$ & $43,607.4$ & $3,738.3$ & $128,048.7$ \\
2000 & 289.0 & $36,200.0$ & $3,100.0$ & $54,455.5$ & $45,997.0$ & na & $140,041.5$ \\
2001 & 621.6 & $16,649.7$ & $2,039.4$ & $54,821.5$ & $49,390.0$ & $2,888.9$ & $126,411.1$ \\
\hline
\end{tabular}

Source: The Gaming Industry News Site, available at: www.lotteryinsider.com.au/stats/world.htm.

The structure of the chapter is as follows. Section 8.2 discusses how a global lottery might work and evaluates the issues in the following sub-sections: lottery operators and their regulation (8.2.1), the market for lotteries (8.2.2), competition between the global lottery and national lotteries (8.2.3), the challenge posed by Internet gambling (8.2.4), revenue-raising potential (8.2.5), cross-county equity (8.2.6), distributional and welfare effects (8.2.7), ethical issues (8.2.8), and development education (8.2.9). Section 8.3 discusses the potential for a global premium bond; we summarize the UK scheme as a model for a global version (8.3.1) and we set out the modalities of a global premium bond and highlight its differences with a global lottery (8.3.2). We conclude (Section 8.4) that global versions of both a lottery and a premium bond are viable and complementary in mobilizing more development finance.

\subsection{A GLOBAL LOTTERY}

How would a global lottery function? Discussions of a global lottery yield two basic possibilities. The first is for national lotteries to run national versions of the global lottery game. The second is a single global lottery sold worldwide and run by one organization. The proposal developed by the CMI, hereafter referred to as the CMI proposal, adopts the first approach (see Ahde et al. 2002). As far as we know, the second approach has not been formally proposed by anyone, but it comes up in discussion because of the possibilities now offered by the Internet. In both versions an agreed international framework is necessary to regulate the lottery organizer(s) and to transfer the money into a global lottery fund to be run by the $\mathrm{UN}$ or another agency (and distributed from there to programmes engaged in development and the provision of global public goods). ${ }^{1}$

\footnotetext{
${ }^{1}$ On global public goods see Kaul et al. (2003).
} 
Lottery products consist of games such as Lotto where the winners are determined by a random draw of numbers, conducted at regular intervals (often weekly in national lotteries) and instant products such as ticket lotteries ('scratch cards') and video lottery terminals (electronic games of chance often simulating popular casino games). A national Lotto game is organizationally more complex and requires more infrastructure than instant games (for this reason, the CMI proposal argues for the introduction of instant ticket lotteries first and a Lotto game at a later stage). Lottery proceeds are divided between winning players, administrative costs, and beneficiaries. In state lotteries in the United States, the proportions are roughly 40-50 per cent (winners), 15-20 per cent (administration), and 30-45 per cent (beneficiaries) (Clotfelter and Cook 1989: 164-5) and the proportions are roughly similar in European lotteries. A key issue for the global lottery is whether to share some of the beneficiaries' portion with national beneficiaries before transferring any money to a global lottery fund. This is a feature of the CMI proposal, which argues that otherwise a global lottery, in competing against national lotteries, may be opposed by governments and national charities. We return to the issue of competition between the global lottery and national lotteries later in the chapter.

National legislatures would be subject to lobbying for and against the global lottery and national debates would inevitably (and rightly) raise questions regarding the basic structure of the global lottery as well as its objectives and ethics. This needs to be paralleled by a well-structured and focused international debate, and international civil society has become very active on issues of international finance in recent years.

Before proceeding further, we must note several other lottery possibilities which are distinct from the global lottery itself. The first is to make development a beneficiary of existing national lotteries. The second is to liberalize national lottery markets in developed countries to permit the marketing of developing-country lotteries. The third is for a developing country (or group of countries) to create their own world lottery product, with themselves as the main beneficiaries. We do not discuss these options in this chapter, but if properly organized they could provide further sources of development finance in addition to the global lottery.

Having set the scene, we now turn to the issues in detail, including our evaluation of the global lottery and its possible modus operandi.

\subsubsection{Lottery Operators and Their Regulation}

National lottery operators range from government agencies and state-owned corporations (as in Sweden) to private corporations, licensed and regulated by government (as in the United Kingdom). About one-third of the world's lotteries are government agencies, and two-thirds are private corporations operating under licence or corporations owned by local or national governments. Accordingly, there is a range of options regarding private versus public providers - whichever version of the global lottery is adopted (the single global lottery or national global lotteries).

The alternative merits of private versus public lottery operation have been extensively debated; older lotteries are often state-run, but newer lotteries tend to be 
private operators who hold the license until the next round of competitive tendering (the United Kingdom, a latecomer to national lotteries, opted for private operation on the grounds that it would raise more revenue than a state-run lottery). If the global lottery is put out to competitive tender for private operation, then the process must be transparent and well regulated. Competitive tendering captures some of the monopoly rents associated with being a lottery provider, thereby raising the amount generated for beneficiaries (development programmes in the case of the global lottery). However, in countries where private operators hold the market monopoly for a fixed period, a national version of the global lottery could not be introduced until the expiry (or renegotiation) of their licenses. Current as well as prospective lottery providers would inevitably lobby to influence the process by which a global lottery is introduced.

It is imperative to run the global lottery efficiently and honestly. This requires a governance structure - to set policy in an overall framework of objectives - as well as regulatory mechanisms. Regulation is by no means straightforward, and economics now has much to say on such problems as 'regulatory capture'. Regulating a single global lottery provider, but with a worldwide operation, is obviously a different challenge to regulating numerous, but national, providers of a global lottery. If the single global provider sells the lottery through the Internet, then the issue of regulation becomes bound up with the larger issue of how to effectively regulate e-commerce (Clarke and Dempsey 2001; O'Connor 2003). If the national variant of the global lottery is chosen, then national lottery operators will fall under the purview of national regulatory authorities, but these vary considerably in their effectiveness. Hence, national regulatory authorities must be overseen by an international authority to ensure that the high standards of a global lottery are met. The World Lottery Association (WLA), a respected international organization with a large membership of national and state lotteries, could play an important role in this regard. Whatever form of international regulatory system is chosen, it must have the ability to impose sanctions and to deregister national global lotteries, which fail to meet the required standards. This will necessitate the creation of a suitable legal framework. And international bodies such as the $\mathrm{UN}$ will have to exercise final oversight.

\subsubsection{The Market for Lotteries}

In a Lotto game, players buy tickets where they choose $n$ numbers from a possible available $N$ numbers and winners receive a share of the prize pool; the design of the game affects the mean, variance and skewness of the prize distribution (Walker and Young 2001: 703; Garrett and Sobel 2002). Empirical evidence shows that ticket sales are an increasing function of the skewness of the prize distribution; players display a preference for games with very few large prizes and some small prizes (Creigh-Tyte and Farrell 1998: 4; Walker and Young 2000: 15). This 'long-shot' bias is evident in other types of gambling (Forrest 2003). Empirical studies show that rollovers (when nobody wins the top prize and the jackpot is added to the jackpot of the next draw) raise sales not only for the draw in question but also for successive draws (Farrell et al. 1999). This is referred to as the 'halo' effect in the industry. Most lotteries suffer 
from 'fatigue'; once the initial excitement of the launch wears off, revenues tend to stagnate or even decline (Creigh-Tyte and Farrell 2003). Periodic redesigns of lotteries are often used to raise excitement and bolster flagging sales - for instance reducing the probability of jackpot winners (e.g. by raising $N$ ) thereby making rollovers more likely.

Since the expected return is lower than the stake, lottery-ticket purchases have puzzled economists and non-pecuniary motives have been much emphasized (Farrell and Hartley 1998). There is a tendency to focus on altruism as a motive for buyers if the lottery funds 'good causes', as with the proposed global lottery or the existing UK national lottery. It is certainly the case that charity-run lotteries can raise sizeable sums; in the United States about US\$6 billion is raised annually in this way, while UK charities derive 8 per cent of their income from their own lotteries (Douglas 1995; Morgan 2000). But some of this may simply be substitution from other forms of charitable giving; there is no evidence on additionality. Evidence on whether the use of funds affects the demand for lottery products is decidedly mixed. In the case of the UK national lottery, 'there is no evidence to suggest that play would be sensitive to the distribution of funds even though individuals may express disapproval over it' (Walker and Young 2000: 29). However, the US state-governments, which earmark lottery proceeds to public goods (e.g. to education), have higher average per capita lottery expenditures than the states which do not (Morgan 2000). And experimental evidence - whereby laboratory participants are asked to choose between lotteriesshows that changes in the desirability of the public good significantly affect gambling behaviour, with gambling falling as the desirability of the offered good falls (Morgan and Sefton 2000). The public goods provided by US state-lotteries benefit many players personally (e.g. as parents). This effect may arise for global lottery players in developing countries, but for players in developed countries it may be of little importance unless development education convinces them that the global lottery will fund global public goods that benefit them personally (see Section 8.2 .9 on development education).

In summary, it appears that the global lottery will face the same design issues as existing lotteries if the objective is to maximize revenues, that is, skew the prize structure towards a few large prizes and encourage rollovers to combat lottery fatigue. The development and global public goods funded by the global lottery will attract people (who we shall call 'global altruists') who are motivated by a desire to help poor countries and combat world problems. And the global lottery's design will determine its entertainment value relative to other lotteries and other forms of gambling, and its entertainment characteristics will significantly affect sales. However, we have not yet finished discussing the market for the global lottery since there is the important issue of competition between the global lottery and national lotteries, to which we must now turn.

\subsubsection{Competition Between the Global Lottery and National Lotteries}

Running right through the debate is a concern that the global lottery may take too much market share from existing national lotteries, leading to opposition by the beneficiaries of existing lotteries (national charities as well as regional and central governments). 
The fear is, therefore, that the global lottery may never get off the ground. Such opposition can certainly be vocal. In the United Kingdom, for instance, charities lobbied hard against the introduction of a national lottery in 1994, fearing its effects on their own charity-lotteries as well as charitable donations overall (UK Parliament 2001). A global lottery would also take market share from private gambling operators; these might be considered 'fair game' for competition — especially when they are unregulated and untaxed Internet operations (see next section). However, the taxation of licensed gambling provides substantial revenue (especially for state governments in Australia and the United States). Private commercial operators will therefore have powerful political friends to lobby against the global lottery's introduction.

Recall that the mean, variance, and skewness of the prize distribution all affect lottery demand, with the empirical evidence showing that ticket buyers prefer higher mean, lower variance, and skewness towards very large prizes (Clotfelter and Cook 1989; Walker and Young 2000: 25). For buyers the global lottery may be more (or less) attractive than competing lotteries along some or all of these moments of the prize-distribution. ${ }^{2}$ Moreover, if a single global lottery is run through the Internet, it will have large economies of scale and its administrative costs will be lower than the aggregate of the administrative costs of existing national lotteries. It would, therefore, have more money to distribute as prizes, another factor giving the global lottery a competitive edge. ${ }^{3}$ Hence, in order to reduce opposition by stakeholders in national lotteries to the global lottery's introduction, it would be necessary to reduce the size of the top prize and the frequency of rollovers (by increasing the odds of winning the top prize). If the global lottery is adjusted in this way, then it will not maximize sales or funds for development, given what we know about the demand for lottery products.

One extra twist arises when the global lottery takes the form of national versions rather than a single globally marketed version. If a national version of the global lottery is designed to have the same prize distribution as the existing national lottery (in order to equalize its attractiveness), then national versions of the global lottery will have different prize distributions across countries since the prize distributions of national lotteries show cross-country variation. If the differences in the distributions of national global lotteries are significantly large, and the transactions costs of cross-border purchase are low, then buyers may prefer to purchase another country's version of the global lottery. There already exist cross-border 'grey markets' in national lotteries, despite national legal prohibitions (e.g. intermediaries sell UK national lottery tickets at a premium in

${ }^{2}$ Assessing the attractiveness of different lotteries to ticket buyers is complicated by the fact that the comparison is between different prize distributions, and not just over the mean prize (given that buyers are influenced by variance and skewness of the distribution in addition to the mean). Such comparisons therefore face the same issues encountered in comparing, for example, distributions of household income and expenditure.

${ }^{3}$ Note that a single monopoly lottery can maximize its revenues by offering a very large jackpot but if a new entrant into a field with a number of existing lotteries attempts to maximize revenues in this way, it will face retaliation; for example, existing lotteries will raise their maximum prize above the level offered by the new entrant, and will reduce the number of smaller prizes. Some existing national lotteries might respond in this way to the introduction of a global lottery. 
Hong Kong). Hence, national lotteries could lose revenues even if their own national global lottery is designed to give an equivalent return. ${ }^{4}$

Any opposition to the global lottery may be reduced if the formula for distributing the resulting global lottery funds (together with their use) are perceived to be in national interests, particularly when global concerns regarding the environment, health and security are seen as bearing on national interests (Section 8.2.6 below discusses the formula). Moreover, if a single global lottery had jackpots sufficiently large to attract pure gamblers, then it might take substantial market shares away from private commercial gambling (which is a US\$1 trillion market, Gaming Board for Great Britain 2003); this would then permit generous 'compensation' to national causes that lose market share to the global lottery.

In summary, to get the necessary support to sell the global lottery in national markets, it is probably the case that the global lottery has to be designed so that it does not maximize sales. Nevertheless, it could still raise significant amounts given the size of the world market for gambling products (and the expected growth in that market).

\subsubsection{The Challenge Posed by Internet Gambling}

The first proposals for a global lottery arose before the Internet age. However, the revolution in information and communications technologies (ICT) is transforming the gambling industry, and this is challenging traditional gambling products including lotteries (the Internet reduces the transaction costs of gambling, especially across borders, and it offers new products which are attractive to gamblers).

A report undertaken for the UK Home Office by the Gaming Board for Great Britain estimates that Internet gambling contributes some US\$32 billion to an annual global gambling turnover of close to US\$1 trillion (a market share of about 3.2 per cent); online lotteries account for US\$7.5 billion of the US\$32 billion (Gaming Board for Great Britain 2003, data for 2001). Most of the online lotteries are run by private operators for private profit, although charities are now moving into this area. The growth of online lotteries (and online gambling) is not confined to developed countries. Indian states such as Maharashtra and Sikkim now operate competing online lotteries using public computer terminals, and private companies compete vigorously for the business of setting up and running India's online state lotteries (BBC 2002a).

Table 8.2 shows the wide range of countries, which provide a base for online gambling. Much of the online gambling is lightly regulated, if at all, and private operators tend to base themselves in jurisdictions with the least regulation, for example, small islands in the Caribbean but also traditional tax havens such as Gibraltar and the British Channel islands. Sophisticated Internet casinos targeted to the large Asian markets operate from the Caribbean. Case law is still being created in the area of Internet gambling as new operators seek to exploit loopholes in existing national laws, or

\footnotetext{
${ }^{4}$ A single global lottery would eliminate the international grey market arising from multiple national versions of the global lottery (and the rents to intermediaries running the grey market would be transferred to the global lottery operator, the prize winners and the beneficiaries).
} 
Table 8.2. Regions with online gambling

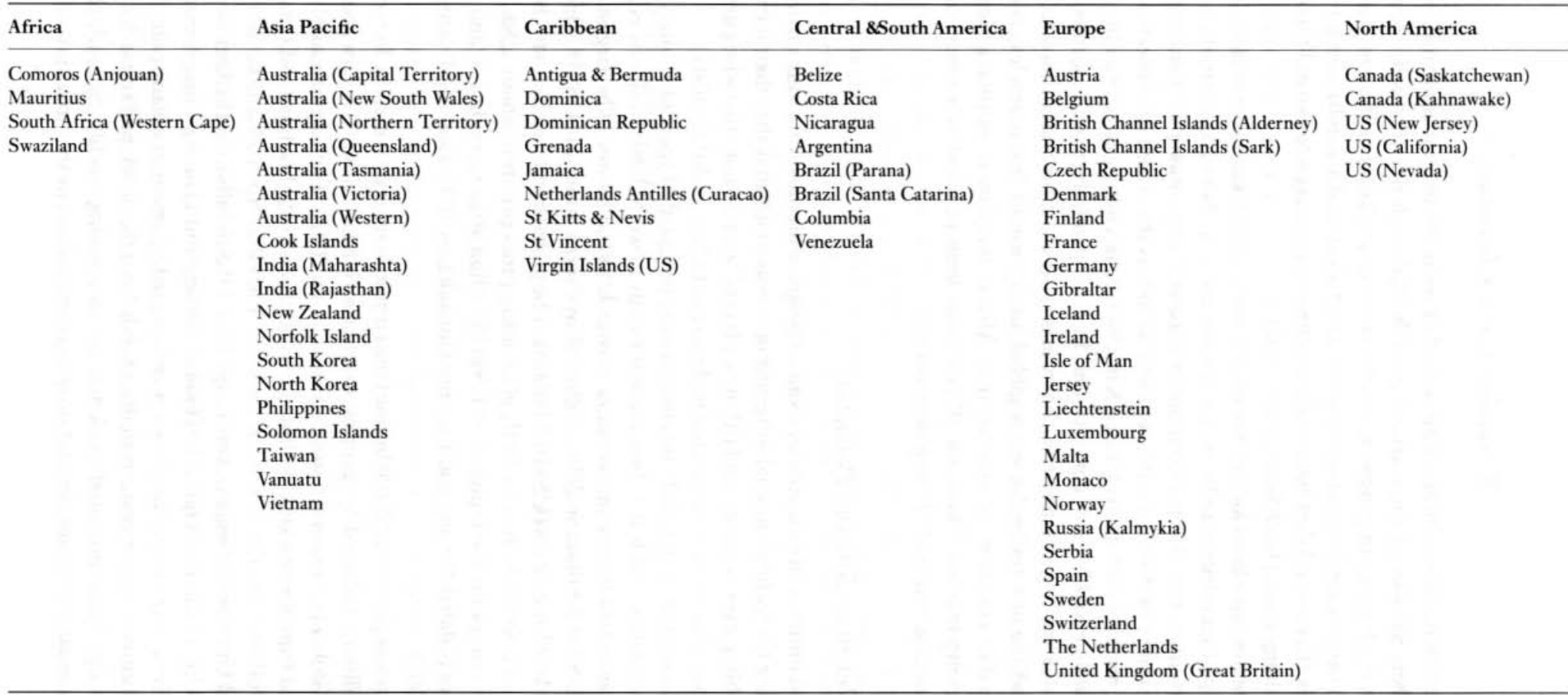

Source: Gambling Licenses.com, available at: www.gamblinglicenses.com/licencesDatabase.cfm. 
circumvent those laws entirely. The refusal of some credit card companies to process Internet bets has slowed the market's growth. Although this threatens some existing operators, the long-term prospects for the Internet market remain strong since major (licensed) casinos are determined to win market share and are influencing US legislation to this effect-and they have political allies in states keen to expand their revenues from gambling taxes (Wall Street Fournal 2003).

In summary, the global lottery will enter a crowded market-place in many countries. In developed countries gamblers can choose not only between a variety of national lottery products but also between an increasingly large menu of gambling options, reflecting the growth of Internet gambling as well as the recent liberalization of major gambling markets such as the United Kingdom. Asia's high-growth gambling markets are now well-served by both domestic and Internet gambling products, many of which are provided by large commercial operators with a sophisticated knowledge of the market and the new technologies. A global lottery would face much less competition in the smaller countries of sub-Saharan Africa, but this is neither a large market nor a growing market. These are all factors to keep in mind as we now turn to the revenue-raising potential of the global lottery.

\subsubsection{Revenue-Raising Potential}

The global lottery will raise money from (i) people who substitute in from other forms of gambling (including national lotteries) or are so motivated that they increase their total gambling expenditures, and (ii) 'new players' who do not otherwise participate in lotteries but who are now motivated to do so (including global altruists).

Any assessment of the likely revenue-raising potential of the global lottery must be highly speculative. Table 8.1 shows recent trends in world lottery sales by region. The total size of world lottery market sales is over US\$120 billion. The largest market is Europe (US\$54.8 billion in 2001), followed by North America (US\$49.4 billion) and Asia and the Middle East (US\$16.7 billion). The global gambling industry had a gross turnover of US\$950 billion in 2001, generating gross profits of about US\$200 billion and net revenues for the industry of US $\$ 115$ billion after taxes, levies, and payments to charities (Global Betting and Gaming Consultants 2002; Gaming Board for Great Britain 2003).

Of the gross profits (US\$200 billion) the largest share is provided by lotteries (about US\$62 billion), followed by gaming machines (US\$58 billion) and casinos (US\$50 billion) (Global Betting and Gaming Consultants 2002). The largest gambling profits are derived from the markets of United States (about US\$61 billion) and Japan (US\$48 billion), followed by the United Kingdom, Australia, Spain, Canada, Italy, France, India, and Germany; these markets range from US\$10 billion in the United Kingdom to about US\$4 billion in Germany (Global Betting and Gaming Consultants 2002).

From these data, we can make two points regarding revenue-raising potential. First, the global lottery will generate most of its funds from the developed countries (although India is a significant potential market in the developing world). Second, these large markets are subject to intense and growing competition in the provision of gambling 
products. Take, for example, the United States, which is the largest market. In 1975 there were thirteen US state-lotteries but by 1999 there were 37, and the 1990s saw the creation of hundreds of legal casinos as fiscal pressures on state governments, and a political reluctance to tax, drove the relaxation of previously tightly controlled markets (Shiller 2000: 41). Similar forces are evident in Australia, India, and South Africa.

If the global lottery took 10 per cent of the 2001 global lottery gross profit (US\$62 billion), then it would raise US\$6.2 billion annually. This compares to total official development assistance (ODA) of US\$59.5 billion in 2001, or aid grants of US\$38.3 billion in 2001 (OECD-DAC data from www.oecd.org/dac).

Developing more sophisticated estimates of global lottery revenues depends on making assumptions regarding the amount that the global lottery will 'capture' from the existing lotteries, substitution away from other forms of gambling, and the amount from new players (including global altruists). All of these assumptions hinge in one way or another on the effectiveness of the marketing of the global lottery, both to pure gamblers and global altruists.

Experience from introducing new national lotteries shows that revenue generation can stagnate as the novelty wears off. This may also be the case for the global lottery. This must be taken into account in the disbursement of funds to development programmes, so as not to endanger delivery (i.e. any special development fund for this purpose may need to retain sizeable reserves). However, the global lottery has a major advantage over national lotteries: its global sales will not suffer as much from the business cycle fluctuations that affect national lottery proceeds, and demand will grow with global income.

\subsubsection{Cross-Country Equity}

As we discussed, countries differ substantially in the potential national market for the lottery. The CMI proposal is for a portion of the national global lottery to be distributed within the country concerned, in order to offset any negative impact on the revenue raised through existing lotteries or the causes they fund.

How should that portion be determined? Should the portion retained by the country be the same across all countries or should it vary according to the level of development (weights based on per capita income) or some form of poverty weighting (using weights derived from UNDP's Human Development Index for instance?). This issue applies not just to the global lottery as an instrument of innovative finance for developing countries, but also to other instruments such as global taxation (and it is part and parcel of any discussion on regional fiscal arrangements such as the European Union's system of contributions and rebates).

We do not resolve this issue here, but a simple example highlights the problem. India has a gross national income of US\$460 per capita and a population of over one billion; Nicaragua has roughly the same per capita income (US\$420) and a population of only 5 million (World Bank 2002: 232-3). For simplicity, assume that per capita annual expenditure on the global lottery is one dollar in each country, so that India sells US\$1 billion of tickets per year and Nicaragua sells US\$5 million (Indians currently 
spend US $\$ 10$ billion annually on lottery tickets; BBC 2002a). If each country transfers the same percentage to the global lottery fund, then India makes a much larger absolute transfer into the fund than Nicaragua. Although large countries will also retain higher absolute amounts for their own causes (including poverty reduction), they may still balk at the scale of their transfers to the global lottery fund and argue for higher percentage retentions for their national causes. There may be a case for a sliding scale; countries with a GNI (gross national income) below some pre-determined level $(X)$ would keep 100 per cent, and countries with a GNI more than $X$ would keep a fraction that falls as their GNI rises.

\subsubsection{Distributional and Welfare Effects}

Empirical evidence for developed countries shows that low-income groups spend a larger proportion of their income on lotteries than higher-income groups. ${ }^{5}$ This implies that lotteries are a regressive way of financing public spending, an aspect that has been much emphasized by their critics (e.g. see, Reno 1997; Fekjoer 2002). ${ }^{6}$ For each dollar bet, the average US state lottery pays 55 cents in prizes, spends 12 cents on retailer commissions and other operating costs, which leaves 33 cents for the state (Clotfelter 2000). Clotfelter and Cook (1989) call this an 'implicit tax' because it has the same effect as a tax on lottery expenditures. Clotfelter (2000: 4) concludes that 'if it were an excise tax, it would amount to a 50 per cent tax on the cost of operating a lottery (67 cents), making it much higher than the excise taxes we place on alcohol or tobacco products'.

UK evidence shows that higher-income groups are more likely to play in rollover weeks when the expected return is higher, presumably because their time carries a higher opportunity cost or they have many other forms of entertainment (Farrell and Walker 1997). Hence, lottery design affects the regressivity of the tax, and if the competitiveness of the global lottery relative to national lotteries is reduced by lowering the top prize (as discussed in Section 8.2.3) then the global lottery tax is likely to be more regressive than existing national and state lotteries.

Compared to ODA financed through an income tax, the global lottery is regressive in its effect on the distribution of income in developed countries. But compared to nothing (i.e. lower development financing in the lottery's absence), it is progressive in terms of the world income distribution - provided that the additional development programmes funded by the global lottery are pro-poor in their impact. When the lottery finances programmes with positive externalities for everyone (e.g. efforts to preserve environmental capital and combat global warming), then the poor benefit along with the non-poor, and these benefits increase when the 'global bad' is especially acute for

${ }^{5}$ In the United States, the 1999 national survey on gambling behaviour found that households with incomes in the range of US\$50,000-99,000 spent an average of US\$301 per year, while households with an income less than US\$10,000 spent an average of US\$520 on lotteries in a year (Federal Reserve Bank of Minneapolis 2003).

${ }^{6}$ See Clotfelter and Cook (1989: 222-3) on defining regressivity in the context of lotteries. 
the poor (e.g. they suffer disproportionately from flooding and drought due to global climate change). Finally, when the poor themselves buy lottery tickets (as many do in South Asia) then as a group the expenditure effect is negative (recall that the expected return in buying a lottery ticket is less than the stake) but some individuals, the winners, may be lifted out of poverty. In summary, the lottery's welfare and distributional effects can be viewed from several different perspectives, some of them more favourable than others.

\subsubsection{Ethical Issues}

Although many countries run lotteries, there are also many critics, and the ethics of the global lottery must be taken seriously and debated at national and international levels. Some religious groups discourage their members from buying lottery tickets, but practices vary widely. Muslim countries vary in their tolerance for lotteries: Bangladesh, Malaysia, and Pakistan have active state lotteries, whereas Saudi Arabia does not. The Catholic religion does not expressly forbid lotteries or gambling, provided that the gambler acts freely and without unjust compulsion. ${ }^{7}$ Many local-level church organizations raise funds from their own lotteries, but gambling is not universally tolerated across all Christian groups. Again, religious organizations would have an important part to play in the national and international debate on the global lottery.

Many people welcome the opportunity to participate in lotteries, judging by the numbers who buy tickets. But equally, gambling addiction can result in personal ruin; of the 125 million Americans who gambled in 1998, some 7.5 million were estimated to be 'problem gamblers' (Shiller 2000: 41 citing data collected by the National Gambling Impact Study Commission). Moreover, gambling addiction appears to be more prevalent in men than women, with catastrophic effects on the household when, as in many countries, men control most of the households' cash income by virtue of their greater participation in wage labour, etc. (see Kearney 2002 on the impact of US state lotteries on consumer expenditures).

So in 'social lotteries', there is always an uneasy tension between the desire to raise money to do good, and the recognition that one is providing a potentially addictive route to ruin, even if only for a small minority of people. For this reason some US state lotteries set aside funds for projects to reduce gambling addiction and some states impose strict controls on advertising (Clotfelter 2000).

The evidence on problem gambling in lotteries is mixed. Griffiths and Wood (1999) review the European research on addiction to lottery gambling. The most addictive forms of gambling are those that give purchasers the chance to gamble continuously (thus slot machines are the most addictive). This also makes scratch cards more of a problem than weekly or bi-weekly lotteries. They conclude that:

With regards to weekly or bi-weekly lotteries there is little evidence Europe-wide that they are addictive. This is primarily because of their low event frequency (i.e. there are a number of days

${ }^{7}$ See the Catholic Encyclopaedia at: www.newadvent.org/cathen/06375b.htm. 
gap between knowing the result of each gamble) ... Scratch cards and VLTs [Video Lottery Terminals] appear to be a different proposition to a discontinuous lottery game and appear to have the potential to promote repetitive habit patterns. Although the evidence is somewhat sparse, there does appear to be evidence in a number of countries ... that scratch cards are a problem to a small minority of people .... (Griffiths and Wood 1999: 21)

In India, lottery gambling has become a matter of public debate, particularly regarding gambling addiction among the poor, and its encouragement by lottery companies. ${ }^{8}$ India's Lotteries (Regulation) Act 1998, bans single digit lotteries and instant lotteries, and bills have been submitted to parliament to ban all lotteries (meeting fierce resistance from state governments, many of which have become increasingly dependent on lottery revenues).

There is also concern over the potentially negative effects of very large prizes on winners (e.g. in press reports regarding family breakdown following lottery wins), leading to the argument that small prizes may be preferable. However, this creates a problem for maximizing lottery revenues given the positive effect of very large prizes on demand. Prizes could be paid in annuities (an option that is offered to winners in the United States), which may reduce such negative social impact.

Despite these problems, many observers might reasonably argue that the ethical case for a global lottery is strong and, indeed, that it is stronger than the case for many existing national lotteries (where national taxation offers more possibilities for meeting social goals if the ethical case for lotteries is in doubt). That is, given the extent of current global problems as well the scale of world poverty and the urgent need to eradicate itrecently reaffirmed by the adoption of the Millennium Development Goals (MDGs) 'exceptional' financing measures are required above and beyond raising foreign aid. And the ethical case for the global lottery will strengthen as the funds it raises deliver tangible progress in meeting the MDGs by their target date of 2015 .

\subsubsection{The Global Lottery's Role in Development Education}

The global lottery has considerable potential as a vehicle for conveying information about development via local sales points together with the national and international media (e.g. through regular advertisements and programmes on commercial (e.g. CNN) and public/semi-commercial TV and radio services (e.g. BBC World).

A single global lottery might be superior to many national versions in its development education impact. Any global televised prize draw would command substantial audiences, affording a unique opportunity to publicize the impact of the funds raised. It would also provide potential for raising additional and large sums from the associated advertising in what could be a peak-viewing slot for a large global audience (for comparison, advertisers paid US\$2 million for a 30-second TV spot during the broadcast of the 2002 US Super Bowl). Any hint of malpractice in the lottery operation or

${ }^{8}$ In 2002, an Indian builder earning US\$3 a day won a US\$1 million jackpot in an online lottery and was taken on a nationwide promotional tour by the lottery company (BBC 2002b). 
misuse of funds would undermine the positive development-education role: caution is therefore recommended.

Development education might be promoted by offering, in addition to a standard global lottery ticket, a menu of lottery tickets (each with the same expected return), the funds from which are earmarked to important causes; for example, tickets to fund primary education, improvements in the livelihoods of poor women, or HIV/AIDS programmes. This might also have positive effects for total funds raised since prospective buyers favour different causes. However, this could reduce the incentive for governments to fund these activities from general taxation or appropriate user charges, thus reducing the net impact - in terms of actual services created - from lottery funds themselves. This issue needs further investigation.

\subsection{A GLOBAL PREMIUM BOND}

\subsubsection{Experiences with National Premium Bonds}

We now turn to a measure, which can complement the global lottery, namely a global premium savings bond modelled on the long-running and successful UK scheme. We describe the UK scheme (and other national premium bond schemes in this section) before turning to the possible structure of the global premium bond in the next section.

In the UK premium bond scheme, people buy savings bonds, each with a unique number that is entered every month in a prize draw, with prizes ranging from $£_{5} 50$ to $£_{1} 1$ million (a random number generator, nicknamed ERNIE, picks the winners). ${ }^{9}$ The size of the total prize allocation is set so that the expected return is equivalent to the yield on UK government stock. Individual bondholders will receive a return above or below the average expected return - depending on their luck and the size of their bond holdings - but in aggregate bondholders get the average if they hold the maximum permitted amount of bonds (which is $£ 30,000$ per person). Winners can opt to reinvest their winnings and many people accumulate sizeable holdings in this way (and since the maximum is per person, not per household, families can potentially hold significant wealth in premium bonds). With average luck, a holder of $£_{u} 30,000$ of bonds will win 12 prizes per year; given the minimum prize of $f_{5} 50$, such an average winner will take home a minimum of $£_{\mathrm{s}} 600$ per year in prizes. Annual premium bond sales are presently running at $£ 21.4$ billion (US $\$ 34$ billion) in the United Kingdom.

Bangladesh and Ireland have similar premium bond schemes. In Bangladesh the 'prize bond scheme' has operated for at least thirty years; the top prize is approximately US $\$ 2000$ and there are many small prizes (there is no limit to the amount that may be held in prize bonds and the prizes are drawn quarterly). For fiscal year 2001-02, US\$815 million was held in prize bonds (Bangladesh Bank 2003).

Premium bondholders never lose their investment (unless the government defaults) but the return depends on their luck. Hence, an individual's return can be above or below that on an interest-bearing deposit account or other types of government bonds.

\footnotetext{
${ }^{9}$ The UK premium bond is managed by the National Savings and Investments Office and is described at: www.nsandi.com.
} 
Investors, who buy premium bonds rather than conventional government bonds, have a preference for skewness in the distribution of returns (also the characteristic of lottery tickets). Many investors favour premium bonds to interest-bearing deposits when interest rates are low (as at present). Their return may fail to match the inflation rate but this is the case for most government bonds. ${ }^{10}$ Premium bonds are much less risky than equities and may produce higher returns than equities over the short-to-medium term given the greater volatility of equity markets. They are also suitable for people in retirement, or closer to retirement, when the main concern is to earn an income from investment in a way that protects the accumulated capital. In addition, winnings are tax free in the United Kingdom; accordingly, higher-rate taxpayers often hold the maximum allowable amount of premium bonds.

However, at this point we should issue a note of caution. Buying premium bonds does contain an element of gambling. You could view a premium bond as equivalent to saving in a savings bank and then using all of the interest in each period to buy lottery tickets. A premium bond offers you the ability to gamble with fewer transactions costs. That said, premium bonds and lottery tickets are incomplete substitutes for three reasons. First, the top prize on a UK premium bond is much less than a UK national lottery jackpot and the prize distribution is less skewed towards very large prizes than is the lottery; given gamblers' preference for skewness, many will still prefer to buy lottery tickets. ${ }^{11}$ Second, you cannot choose the numbers of your UK premium bond (bondholders are allocated a number), whereas this is important to the lottery's entertainment value. ${ }^{12}$ Third, a premium bond offers less ex post regret. If you buy $£_{0} 100$ of lottery tickets over a year and win nothing, then you lose $f_{\omega} 100$, but if you buy $f_{1} 100$ of premium bonds and win nothing then you forfeit the interest from holding the money in a savings account (or other alternative investment). This is important given that most people consistently overestimate expected returns - whether on lottery tickets, premium bonds, or equities (see Clotfelter and Cook 1989 on lotteries and Shiller 2000: 142 on 'irrational exuberance' in equity markets).

In summary, a premium bond is like a lottery ticket in that the return depends on a random prize draw, but otherwise the premium bond is a savings instrument (with some entertainment value) whereas a lottery ticket is closer to other types of entertainment expenditure. Hence it can make financial sense to make a sizeable investment in premium bonds while it is very unwise to bet a large sum on a lottery. Premium bonds have a potentially wider market since their purchase is more socially acceptable to groups who otherwise avoid lotteries; in the United Kingdom, they are often given as gifts, especially to children (also the case with Bangladesh's prize bonds).

${ }^{10}$ United States Treasury Inflation Protected Securities (TIPS) are a major exception.

11 The take-up of premium bonds in the United Kingdom was quite slow until the prize structure was redesigned to make it more appealing to gamblers (Rayner 1969, 1970).

${ }^{12}$ It may be possible to design a system whereby premium bondholders select their draw numbers each month if they wish; the bond number would then carry a permanent reference number purely to record ownership. 


\subsubsection{The Modalities of A Global Premium Bond}

Whereas a global lottery can be run in either national versions or a single (international) version (see Section 8.2), a global premium bond (which henceforth we shall call a 'global ERNIE') is a more complex instrument and would be best managed by a single organization (selling the bonds through national sales offices and/or the Internet). It is advantageous, for reasons discussed later, for the global ERNIE to be denominated in a major currency (or basket of major currencies to offset exchange rate risk for bondholders). The flow of funds in and out of the global ERNIE will be subject to changes in its rate of return relative to other financial instruments (e.g. other bonds and equities). The global ERNIE must be liquid and well managed (and its credibility will be strengthened if the world's financial authorities conduct close oversight).

A premium bond is a debt instrument, the bondholder lends his or her money and is entitled to repayment upon request, in contrast to a lottery ticket that is a nonrefundable expenditure. ${ }^{13}$ This has implications for the use to which the money can be put. A global lottery can provide grant finance for development purposes, whereas a global ERNIE is more suited to providing loan finance. If the UK model is followed and the expected return for an individual holding the maximum permitted amount of bonds is linked to the return on a comparable financial instrument (for instance, a weighted average of the yield on a basket of developed-country government bonds) then this (plus associated administrative costs) sets a lower bound on the lending rate unless some element of subsidy from other sources is provided (from the funds raised by the global lottery, for example). This means that eligible borrowers, who could be developing-country governments, NGOs and international organizations, could borrow on terms as good as those facing rich-country governments (but on less concessional terms than IDA, unless a subsidy is provided).

Default by borrowers is always possible, but this is true for any loan instrument; thus the desirability of ERNIE funded-lending is bound up with the larger question of whether grants or loans are preferable for low-income countries, an issue which is hotly debated in the context of the heavily indebted poor country (HIPC) Initiative (Addison et al. 2004). Default could, in extremis, be absorbed by lowering the rate of expected return to bondholders and raising the lending rate to borrowers, but this would reduce the attractiveness of global ERNIEs to investors. Large-scale default would throw into question the repayment of the principal, with potentially fatal results for the viability of the scheme. In addition, since bonds are redeemable on demand, whereas loans are long-term, there is mismatch in the maturity structure of assets and liabilities. This mismatch is similar to that found in bond-financed mortgage markets and in the United States the government acts as the guarantor (through Freddie Mac and Fannie Mae). In the case of the global ERNIE, the guarantors could be rich-country governments (the G7 group) or emerging economies with sizeable foreign-exchange reserves (for instance, China and India).

${ }^{13}$ UK Premium bonds do not have a fixed term (as is the case with government and corporate debt). 
As a financial instrument the global ERNIE would have the following qualities:

1. It would be an attractive savings instrument in its own right, particularly for 'ethical' investors. Ethical investment products are a rapidly growing market, both for individuals (e.g. pension investment) but also for charitable foundations (a large market). From the perspectives of risk management and return, ethical investors need to hold bonds but they face a dilemma in holding government paper; they cannot avoid financing categories of state spending (e.g. the military, nuclear power, etc.) that they deem to be unethical (whereas ethical investors in equities can pick and choose across companies, excluding those that are unethical). This class of investors will provide a strong source of demand for a global ERNIE.

2. The global ERNIE would widen the range of savings instruments open to individuals and organizations (including NGOs as well as private and public organizations) in developing countries that are often ill-served by domestic financial instruments. It would provide a useful hedge against the inflation and currency risk arising from holding savings in domestic assets, especially in countries with weak currencies and high inflation, since it will be denominated in a convertible foreign currency (or preferably a basket of foreign currencies so as to stabilize its global purchasing power-this also reduces the exchange rate risk for bond buyers in major currency countries). Migrants making remittances home could also purchase global ERNIEs for their families (see Chapter 9, this volume). Note that a conventional international bond, if made available to developing-country citizens, could also fulfil the function of widening the range of savings instruments, so this benefit is not exclusive to the global ERNIE alone.

3. Global ERNIE's would be a suitable charity gift, including transfers between individuals or groups in developed and developing countries, and such gifts and bequests could be exempted from taxation under national legislation to increase their attractiveness (however, a limit on purchases would be necessary to avoid the crowding-out of taxable bonds). International charities could also hold global ERNIEs on behalf of community organizations in countries and localities with insecure property rights and poor communications.

4. The global ERNIE may over time establish itself as a collateral instrument that people can borrow against in their domestic capital markets, both informal and formal (to the advantage of poorer ERNIE holders who can diversify their collateral away from traditional instruments such as land, cattle, jewellery, and bonded labour). ${ }^{14}$

These potential development and welfare benefits of a global ERNIE are independent of the use to which the funds are put by international development agencies (and would also apply to any conventional bond made available to developing-country buyers which

${ }^{14}$ If ERNIEs were bearer bonds, then their use as collateral would be facilitated but this is almost certainly ruled out by the necessity to impose a maximum limit on the holding per person (as in the UK scheme) and the ease with which bearer bonds can be used in money laundering. 
indicates an important gap in the market irrespective of whether one favours a global premium bond or not). ${ }^{15}$

In summary, the global lottery is superior to the global ERNIE from the perspective of the final user of the funds, since the lottery can provide finance on grant terms. But the lottery does not offer a savings instrument, whereas the premium bond does and, provided that the risks of borrower default are contained, the global ERNIE could be attractive to investors in both developed and developing countries. This would facilitate ethical investment in developing countries and provide individuals and organizations in developing countries with access to an international financial instrument.

The global ERNIE may be more ethically acceptable to those who disagree with gambling in general. Since the funds raised by existing national premium bonds are not earmarked to charitable causes (as is often the case with government lotteries), but instead form part of general government funding, there would not be the level of resistance among national charities that poses a political problem for the global lottery (rather the opposition might arise from ministers of finance who see the global ERNIE as taking market share from their country's domestic debt instruments).

Finally there is an issue of sequencing the introduction of the global lottery and the global premium bond. As we noted in Section 8.2.1, the introduction of the global lottery may be delayed when national lottery suppliers hold licences for defined periods. Being a different product, the global premium bond could be introduced earlier.

\subsection{CONCLUSION AND RECOMMENDATIONS}

This chapter has discussed the present proposals for a global lottery. This has potential for raising finance for development programmes and programmes to provide global public goods. In addition, we have proposed a global premium bond as an additional instrument. Both the lottery and the global ERNIE could have strong development education benefits, an important consideration in these days of 'aid fatigue', when the case for helping poor countries and poor people must again capture the public's imagination. But for this reason, both schemes must meet the highest possible ethical standards.

The global ICT revolution is fundamentally changing the market for gambling. It is now possible to conceive of running the global lottery from a single organization via the Internet. This would have significantly lower administrative costs than selling national versions of the global lottery through national lottery agencies; a single authority would be easier to regulate than many national authorities and it would have potentially greater reach than national schemes. But for these reasons it may face more political opposition than nationally run versions of the global lottery if it is seen to take money from national charities and treasuries. We do not envision nationally run versions of the global ERNIE since this is a more complex financial instrument than the lottery.

15 We are grateful to an anonymous referee for this point. 
The market for gambling is also being liberalized in many countries. Liberalization is driven by the fiscal needs of central and local governments (including the increasing importance of gambling taxes arising from political opposition to other forms of taxation), the liberalization of cross-border transactions in services (e.g. EU harmonization) and more permissive social attitudes to gambling. In the United Kingdom for example, the report of the Gambling Review Body, chaired by Sir Alan Budd, recommended relaxing legal restrictions on the advertising and promotion of gambling, in part to create a fairer and more competitive market for gamblers (UK Department for Culture, Media and Sport 2003). A global lottery will have to compete in an increasingly vigorous market.

Global altruism can play a big role in encouraging sales of the global lottery-hence the importance of the development education component-but sizeable sales depend as well on its attractiveness to gamblers relative to other gambling products, including those now provided commercially via the Internet. In contrast, the attractiveness of the global ERNIE depends more on its merits as a savings instruments and we argue that it could find a strong place in the growing market for ethical investments. Whatever the final design of such schemes, it is imperative that we move ahead with further debate on these and other innovative forms of development finance.

\section{REFERENCES}

Addison, T., H. Hansen, and F. Tarp (eds) (2004). Debt Relief for Poor Countries. Basingstoke: Palgrave Macmillan for UNU-WIDER.

Ahde, M., A. Pentikäinen, and J-M. Seppänen (2002). 'Global Lottery'. Prepared for the Ministry of Foreign Affairs of Finland, 8 March. Helsinki: Office of President Ahtisaari (Crisis Management Initiative).

Bangladesh Bank (2003). 'Economic Trends'. Dhaka. Available at: www.bangladeshbank.org/pub/monthly/econtrds/exnotes.html. Accessed 17 April 2003.

BBC (2002a). 'India's Online Lottery: It's a Rollover!'. BBC News, 30 March. Available at: news.bbc.co.uk $/ 1 / \mathrm{hi} /$ world/south_asia/1901203.stm.

- (2002b). 'Indian Pauper Strikes Lottery Gold'. BBC News, 3 July. Available at: news.bbc.co.uk/2/hi/south_asia/2091523.stm.

Childers, E. and B. Urquhart (1994). Renewing the United Nations System. Uppsala: Dag Hammarskjold Foundation.

Clarke, R. and G. Dempsey (2001). 'The Feasibility of Regulating Gambling on the Internet'. Managerial and Decision Economics, 22: 125-32.

Clotfelter, C. T. (2000). 'Do Lotteries Hurt the Poor? Well, Yes and No'. A Summary of Testimony Given to the House Select Committee on a State Lottery, 28 April.

— and P. Cook (1989). Selling Hope: State Lotteries in America. Cambridge, MA: Harvard University Press.

Creigh-Tyte, S. and L. Farrell (1998). 'The Economics of the National Lottery'. Working Paper 190. Durham: University of Durham.

(2003). 'Is the UK National Lottery Experiencing Lottery Fatigue?', in L. V. Williams

(ed.), The Economics of Gambling. London: Routledge, 165-81.

Douglas, A. (1995). British Charitable Gambling 1956-1994. London: Athlone Press. 
Farrell, L. and I. Walker (1997). 'It Could Be You! But What's It Worth? The Welfare Gain from Lotto'. Working Paper 97/4. London: Institute of Fiscal Studies.

— and R. Hartley (1998). 'Can Friedman-Savage Utility Functions Explain Gambling?'. Working Paper No. 98/02. Keele: Department of Economics, Keele University.

_ E. Morgenroth, and I. Walker (1999). 'A Time Series Analysis of UK Lottery Sales: The Long-Run Price Elasticity'. Oxford Bulletin of Economics and Statistics, 61(4): 513-26.

Federal Reserve Bank of Minneapolis (2003). 'Taking Food from Mouths?'. FedGazzette, March.

Fekjoer, H. O. (2002). 'Gambling as Taxation of the Poor'. Paper presented at the EASG Conference, 4 October, Barcelona. Available at: www.bks.no/barcelon.htm. Accessed on 16 April 2003.

Forrest, D. (2003). 'Time Series Modelling of Lotto Demand', in L. V. Williams (ed.), The Economics of Gambling. London: Routledge, 182-203.

(The) Gaming Industry News Site. Available at: www.lotteryinsider.com.au/stats/world.htm .

Gaming Board for Great Britain (2003). 'Internet Gambling: Report to the Home Secretary by the Gaming Board for Great Britain'. Available at: www.gbgb.org.uk/intgambling_main.html. Accessed on 2 April 2003.

Garrett, T. A. and R. S. Sobel (2002). 'State Lottery Revenue: The Importance of Game Characteristics'. Working Paper 2002-011A. St Louis, MO: Federal Reserve Bank of St Louis. Available at: www.research.stlouisfed.org/wp/2002/2002-011.pdf.

Global Betting and Gaming Consultants (2002). 'Betting and Gaming Industry Becomes a Global Proposition'. Press Release, 15 July. Available at: www.bettingconsultants.com.

Griffiths, M. D. and R. T. A. Wood (1999). 'Lottery Gambling and Addiction: An Overview of European Research'. Report compiled for the Association of European National Lotteries (AELLE) Lausanne, Switzerland. Nottingham: Psychology Division, Nottingham Trent University. Mimeo.

Kaul, I. P., P. Conceição, K. Le Goulven, and R. U. Mendoza (eds) (2003). Providing Global Public Goods. Oxford: Oxford University Press for UNDP.

Kearney, M. S. (2002). 'State Lotteries and Consumer Behaviour'. NBER Working Paper 9330. Cambridge, MA: National Bureau of Economic Research. Available at: www.nber.org/papers/w9330.

Morgan, J. (2000). 'Financing Public Goods by Means of Lotteries'. Review of Economic Studies, 67: 761-84.

- and M. Sefton (2000). 'Funding Public Goods through Lotteries: Experimental Evidence'. Review of Economic Studies, 67: 785-810.

O'Connor, N. (2003). 'Online Betting and the Law'. Available at: www.bettingmarket.com/law2.htm. Accessed 6 March 2003.

Rayner, A. C. (1969). 'Premium Bonds - the Effect of the Prize Structure'. Bulletin of the Oxford Institute of Economics and Statistics, 31(4): 303-11.

- (1970). 'Premium Bonds-A Postscript'. Bulletin of the Oxford Institute of Economics and Statistics, 32(2): 167-9.

Reno, R. (1997). 'Gambling and the Poor'. Citizen Link. Available at: www.family.org/cforum/research/papers/a0004190.html. Accessed 1 April 2003.

Shiller, R. J. ( 2000). Irrational Exuberance. Princeton, NJ: Princeton University Press.

UK Department for Culture, Media, and Sport (2003). 'Modernising Britain's Gambling Laws: Draft Gambling Bill'. London: The Stationary Office.

UK Parliament (2001). 'Memorandum Submitted by the National Council for Voluntary Organizations to the Select Committee on Culture, Media and Sport: Minutes of Evidence'. London: UK Parliament. Available at: www.parliament.the-stationary-office.co.uk. 
Walker, I. and J. Young (2000). 'The Dummies' Guide to Lottery Design'. Warwick Economic Research Papers 572. Warwick: Department of Economics, University of Warwick. (2001). 'An Economist's Guide to Lottery Design'. Economic Fournal, 111(November): F700-22.

Wall Street fournal (2003). 'Curbs on Web Gambling Supported'. 22 August.

World Bank (2002). World Development Report 2002: Building Institutions for Markets. Oxford: Oxford University Press for the World Bank. 